NUKHBATUL 'ULUM : Jurnal Bidang Kajian Islam

Vol. 6, No. 1 (2020) : Hal. 122-135

Website: https://journal.stiba.ac.id

ISSN : 2685-7537 (online); 2338-5251 (Printed)

\title{
HUKUM PENISBAHAN SIFAT PENCIPTA PADA MANUSIA DAN HUBUNGANNYA DENGAN PEMAHAMAN QADARIYAH
}

\section{Rule of Atribution of Creator to Mandkind and Its Relation to the Qadariyah's Believes}

\author{
Abdullah Nazhim Hamid \\ Sekolah Tinggi Ilmu Islam dan Bahasa Arab (STIBA) Makassar \\ Email: abufauzangeologi@gmail.com
}

\author{
Awal Rifai \\ Sekolah Tinggi Ilmu Islam dan Bahasa Arab (STIBA) Makassar \\ Email: awalrifai1991@gmail.com
}

\begin{abstract}
Keywords : $\quad$ ABSTRACT
Atribution, al-khalqu, attribute, This research was aiming to know the rule of atribution of creator to mandkind qadariyah, syirk. and its relation to the Qadariyah's believes. This research used the library
review methods by collecting the views of the scholars from the linguist of
Arabic Langiage, Quran Interpreters, and generalist scholars which are have
concern abaout the Islamic doctrines. The Result of The Research showed that
of word al-khalqu in Arabic has two meanings, the first meaning is to put
something out of nothingness to existance and the second is to invent or make
or produce or transform of one nature into another. Therefore, the rule of this
atribituon is depends on two conditions, the purpose of using the word "creator"
and its object. If the word "creator" based on the second meaning, and the
object is the things are still in human capacity and reasoning then the using is
allowed. However, if those two conditions are not fulfilled, then the using is
prohibited. Moreover, if the attribution is related to the human act and
accompanied by the belief that there is no divine intervention and human is the
main cause of his creation, then it is closely related to the Qadariyah
understanding.

Penisbahan, al-khalqu, sifat, Penelitian ini dilakukan dengan tujuan untuk mengetahui hukum menggunakan qadariyah, syirik. dan menisbahkan sifat pencipta kepada manusia dan hubungannya dengan paham Qadariyah. Penelitian ini menggunakan metode kajian pustaka dengan mengumpulkan referensi-referensi menurut pandangan ulama ahli Bahasa Arab, ulama-ulama ahli tafsir dan ulama-ulama generalis. Hasil dari pengkajian ini memperlihatkan bahwa makna kata menciptakan dalam bahasa Arab adalah mengeluarkan sesuatu dari ketiadaan menuju ada, dan juga bermakna membuat. Sehingga hukum penisbahan kata "menciptakan" tersebut tergantung dari makna kata dan objeknya. Jika yang dimaksud dengan pencipta adalah pembuat atau produsen atau pengubah dari satu sifat ke sifat yang lain, dan objek dari kata itu adalah hal-hal yang masih dalam kemampuan manusia secara nalar dan logika maka penggunaannya menjadi boleh. Adapun jika kedua hal tersebut tidak terpenuhi maka ini tergolong ke dalam kesyirikan. Terlebih lagi jika penisbahan sifat pencipta ini dalam hal perbuatan manusia dibarengi dengan keyakinan tidak adanya campur tangan Allah dan semata-mata manusialah yang menjadi sebab utama terjadinya perbuatannya, maka ini sangat erat hubungannya dengan pemahaman Qadariyah.
\end{abstract}

Riwayat artikel: Diterima: 8 April 2020; Direvisi: 28 Mei 2020; Disetujui: 28 Mei 2020; Tersedia online: 12 Juni 2020.

How to cite: Hamid, A. N., Rifai, A. (2020). Hukum Penisbahan Sifat Pencipta pada Manusia dan Hubungannya dengan Pemahaman Qadariyah. NUKHBATUL 'ULUM: Jurnal Bidang Kajian Islam, 6(1), 122-135. https://doi.org/10.36701/nukhbah.v6i1.118 


\section{PENDAHULUAN}

Kata "menciptakan" atau "pencipta" adalah kata yang sangat lumrah digunakan dalam kehidupan sehari-hari dan sangat atributif. Sering kita temukan kata tersebut disandarkan kepada Allah ataupun tuhan dan dewa secara umum bagi agama selain Islam. Namun, ternyata kata tersebut tidak hanya kita dapatkan dalam konteks teologis saja, tapi dalam aspek sosiologis juga. Sering kali kita temukan penyandaran kata tersebut pada manusia seperti pernyataan, "menciptakan lapangan kerja," "menciptakan kebahagiaan," "menciptakan kader yang militant," "menciptakan masa depan," "pencipta lagu," "pencipta alat," dan ungkapan-ungkapan yang senada dengan itu. Padahal dalam akidah Islam yang harus diyakini sebagai satu-satunya pencipta segalanya adalah Allah Ta'ala. ${ }^{1}$

Allah adalah satu-satunya pencipta, sebagaimana Ia telah mengafirmasinya sekaligus menegasikan pencipta-pencipta selainNya dalam firman-firman-Nya seperti, "Ingatlah, segala penciptaan dan urusan menjadi hak-Nya"[2][3]. Pada ayat yang lain, Allah berfirman "Adakah pencipta selain Allah yang dapat memberikan rezeki kepadamu dari langit dan bumi? ${ }^{[4][5]}$, serta firman-Nya, “Apakah mereka menjadikan sekutu-sekutu bagi Allah yang dapat menciptakan seperti ciptaan-Nya sehingga kedua ciptaan serupa menurut pandangan mereka?."[6][7] Dua ayat terakhir yang disebutkan memang jika dilihat bentuknya adalah pertanyaan, namun pertanyaan-pertanyaan pada ayat itu menunjukkan makna pengingkaran ${ }^{8}$ dimana hal ini disebut al-istifhām al-inkārí yang merupakan salah satu gaya bahasa al-Quran berupa pertanyaan tanpa jawaban, sehingga pendengar ayat-ayat semacam inilah yang akan menjawab sesuai fitrahnya dan akan lebih mengena pada hatinya. ${ }^{9}$ Pada ayat terakhir surah alHasyr, Allah menyebutkan tiga di antara nama-nama-Nya yang indah yaitu alKhāliq, al-Bāri' dan al-Musawwir dimana nama-nama tersebut sebagaimana kata al-Sa'di, berhubungan dengan sifat penciptaan, pengaturan dan penetapan yang

\footnotetext{
${ }^{1}$ Al-Qur'an, Al-An'am/6: 102, Al-Ra'd/13: 16, Al-Zumar/39: 62, Ghafir/40: 62.

${ }^{2}$ Al-Qur'an, Al-A'raf/7: 54.

${ }^{3}$ Departemen Agama RI, Al-Quran Dan Terjemahannya (Jakarta: Darussalam, 2006). h. 211.

${ }^{4}$ Al-Qur'an, Fathir/35: 3.

${ }^{5} \mathrm{RI}$, Al-Quran Dan Terjemahannya. h. 616.

${ }^{6} \mathrm{Al}-\mathrm{Qur}$ 'an, Al-Ra'd/13: 16.

${ }^{7}$ RI, Al-Quran Dan Terjemahannya. h. 339. 1984), h. 254

${ }^{8}$ Muhammad Ṭāhir bin 'Āsyūr Al-Tūnisīi, Al-Tahrīir Wa Al-Tanwīi, vol 22. (Tunisia: Al-dār Al-Tūnisiah, h. 350 .

${ }^{9}$ Muhammad Malkawī, 'Aqīdah Al-Tauhid Fī Al-Qurān Al-Karīm (Madinah: Maktabah Dār Al-Zamān, 1985),
}

Abdullah Nazhim Hamid, Awal Rifai. Hukum Penisbahan Sifat... 
terkhusus hanya untuk Allah Ta'ala dan tidak ada yang ikut serta dalam sifatsifat tersebut. ${ }^{10}$

Rasulullah saw. dalam sabdanya juga telah menegaskan bahwa Allah adalah satusatunya pencipta sebagaimana dalam hadis yang diriwayatkan oleh al-Bukhāri nomor 5953, ketika $A b \bar{u}$ Hurairah melihat adanya lukisan makhluk bernyawa di salah satu rumah penduduk Madinah, lalu beliau berkata, "Saya telah mendengar Rasulullah bersabda, 'Siapakah yang lebih zalim daripada orang yang pergi membuat ciptaan seperti ciptaanku?",

Dalam makna tauhìd rubübiyyah yang menjadi bagian dari tri tauhid adalah meyakini dan mengesakan Allah sebagai pencipta. ${ }^{[12][13]}$ Berdasarkan hal tersebut kita mengafirmasi bahwa Allah mempunyai sifat al-Khalqu(الخلق) yang bermakna mengadakan semua hal dari ketiadaan sebagaimana yang dinyatakan oleh Ibnu Taimiyah. $^{14}$

Penisbahan sifat pencipta kepada manusia terutama pada hal-hal yang berhubungan dengan perbuatan manusia adalah mempunyai kemiripan terhadap salah satu pemahaman dalam dunia Islam yaitu pemahaman Qadariyah yang muncul pada zaman sahabat. Qadariyah sendiri terbagi menjadi dua yaitu Qadariyah ekstrim dan Qadariyah moderat. Qadariyah ekstrim ialah bermula dari seseorang yang bernama Ma'bad Al-Juhanī yang menafikan takdir dan ilmu Allah serta mengatakan bahwa manusialah yang menciptakan perbuatannya dan bukan Allah, adapun Qadariyah moderat, pemahaman mereka lebih ringan dari kelompok pertama. ${ }^{15}$ Anggapan ini lahir karena mereka ingin mensucikan Allah dari sifat zalim, mereka beranggapan bagaimana mungkin Allah menyiksa orang kafir di neraka sementara Allah sendiri yang menciptakan kekafiran tersebut dan menghendaki serta menakdirkan orang tersebut menjadi kafir. ${ }^{16}$ Sehingga mereka pun berkeyakinan bahwa adanya takdir merupakan kezaliman dan manusialah yang punya kehendak dan pilihan tanpa ada campur tangan dari Allah, serta manusialah yang menciptakan perbuatannya sendiri.

Keyakinan sekte Qadariyah yang ingin digarisbawahi dalam penelitian ini adalah keyakinan bahwa Allah tidak menciptakan perbuatan manusia yang baik ataupun

\footnotetext{
${ }^{10}$ Abd Al-Raḥmān bin Nāsir Al-Sa'di, Taisīru Karīmi Al-Rậmān Fī Tafsīiri Kalāmi Al-Mannān (Dammam: Dār Ibnu Al-Jauzì, 2011), h. 1015.

${ }^{11}$ Muhammad bin Ismā'il Al-Bukhārì, Sahīh Al-Bukhārīi, Vol. 7 (Beirut: Dār Țūq Al-Najāh, 2001). h. 167.

${ }^{12}$ Sulaimān bin 'Abdullah bin Muhammad bin 'Abd Al-Wahhab, Taisìir Al-'Azizz Al-Hạmìd (Beirut: Al-Maktab Al-Islāmìi, 2002), h. 17.

${ }^{13}$ Muhammad bin Șālih Al-Ùsaimīn, Al-Qaul Al-Mufíd (Arab Saudi: Dār Ibnu Al-Jauzīi, 2016), h. 8. 1995), h. 357

${ }^{14}$ Taqiyyuddin Aḥmad Ibnu Taimiyah Al-Dimasyqūi, Majmū' Al-Fatāwā vol. 6 (Madinah: Majma' Malik Fahd,

${ }^{15}$ Ḥăfiz bin Ahmad Al-Ḥakamī, Ma'âriju Al-Qabūl (Dammam: Dār Ibnu Al-Qayyim, 1990). h. 943-954.

16 ‘Umar bin Sulaimān Al-Asyqar, Al-Qadhā’ Wa Al-Qadar (Oman: Dār Al-Nafäis, 2000). h. 58.
} 
yang buruk, namun yang menciptakannya adalah manusia itu sendiri. ${ }^{17}$ Tentu pemahaman ini menyelisihi akidah Islam yang benar, Allah berfirman, "Padahal Allah-lah yang menciptakan kamu dan dan apa yang kamu perbuat itu." "[18][19] AlBukhārī juga mengatakan bahwa para ulama telah mendeklarasikan bahwa "menciptakan" adalah sifat dari Allah dan perbuatan kita adalah adalah ciptaan Allah, dimana beliau berdalilkan dengan firman Allah, "Dan rahasiakanlah perkataanmu atau nyatakanlah. Sungguh, Dia maha mengetahui segala isi hati. Apakah (pantas) Allah yang menciptakan itu tidak mengetahui?'[20 ][ 21 ] maksudnya Allah-lah yang menciptakan perkataan yang disembunyikan ataupun yang ditampakkan. ${ }^{22}$ Ibnu Taimiyah juga menyatakan bahwa pernyataan Qadariyah tentang manusia yang menciptakan perbuatannya adalah bentuk afirmasi sifat pencipta kepada selain Allah, padahal ulama-ulama ahlusunah termasuk para sahabat Nabi telah membantahnya seperti Abdullah bin 'Umardan selainnya. $^{23}$

Pada sisi lain, terdapat firman Allah yang berbunyi, "Maha suci Allah pencipta yang paling baik," jika kita perhatikan ayat ini seakan-akan ada pencipta selain Allah dan Allah-lah yang paling baik, tentu ini ini ada sebuah kontradiksi dimana di ayat-ayat yang lain Allah menyatakan bahwa Dialah satu-satunya pencipta. Pada ayat yang lain juga ternyata kata khalaqa ini kita dapatkan dalam al-Qur' an disematkan kepada makhluk seperti pada surah Ali Imran/3:49 dan surah AlAnkabut/29:17. Selain itu, di al-Qur'an kita juga bisa dapatkan kata al-khalqu disematkan pada makhluk sebagaimana di hadis yang diriwayatkan oleh alBukhärī nomor 2105, ketika Nabi saw. melihat gambar bernyawa pada sebuah bantal yang dibeli oleh Aisyah ra., beliau bersabda, "Sesungguhnya orang-orang yang menggambar ini akan diazab pada hari kiamat lalu dikatakan kepada mereka "hidupkanlah apa yang kalian telah ciptakan." ${ }^{24}$ Hal ini seakan-akan mengandung kontradiksi dimana di satu sisi Allah menegaskan bahwa Dialah satu-satunya pencipta, namun di sisi lain Allah menisbahkan sifat pencipta kepada makhluk. Olehnya itu perlu dibahas secara komprehensif apa hukum dari penyandaran sifat pencipta kepada makhluk.

Penelitian ini menekankan pada hukum penisbahan sifat pencipta kepada manusia, apakah hal ini boleh secara mutlak atau termasuk syirik sehingga tidak

\footnotetext{
17 'Abd Al-Qāhir Al-Bagdāđí, Al-Farqu Baina Al-Firaq (Beirut: Dār Al-Affāq Al-Jadìdah, 1977), h. 94.

${ }^{18}$ Al-Qur'an, Al-Saffat/37: 96.

${ }^{19}$ RI, Al-Quran Dan Terjemahannya, h. 640.

${ }^{20} \mathrm{Al}-\mathrm{Qur}$ 'an, Al-Mulk/67: 13-14.

${ }^{21}$ RI, Al-Quran Dan Terjemahannya, h. 823.

${ }^{22}$ Muhammad bin Ismā'̄il Al-Bukhārì, Khalqu Af'āl Al-'Ibād (Jeddah: Dār Al-Ikāz, 1978), h. 114.

${ }^{23}$ Al-Dimasyqī, Majmū' Al-Fatāwă, vol. 12 (Madinah: Majma' Malik Fahd, 1995), h. 327-328.

${ }^{24}$ Al-Bukhāri, Sahīh Al-Bukhārīi. Vol. 3 (Beirut: Dār Țūq Al-Najāh, 2001). h. 63.
} 
boleh dilakukan secara mutlak, dan jika memang demikian, apakah hal ini termasuk dalam keyakinan sekte Qadariyah ataukah hanya sekedar syirik kecil.

Penelitian terdahulu yang mempunyai singgungan dalam penelitian ini di antaranya adalah kajian Muhammad Muhlis dengan judul penelitian "Dimensi Syirik dalam Konteks Privatisasi Beragama Islam." ${ }^{25}$ Dalam penelitian tersebut peneliti menjelaskan tentang sepuluh pembatal keislaman yang dibawakan oleh Muhammad bin Abd Al-Wahhāb. Salah satu yang menjadi bahasannya adalah syirik yang merupakan pelanggaran hak prerogatif Allah dan kemutlakannya mencakup syirik besar ataupun syirik kecil. Namun, dalam penelitian tersebut tidak diperinci perihal contoh-contoh syirik secara detail. Olehnya itu, penelitian ini mencoba mengungkap apakah penyandaran sifat pencipta kepada manusia termasuk syirik secara mutlak karena sifat pencipta yang dibahas dalam penelitian ini juga merupakan hak prerogatif Allah.

Selain penelitian di atas di antara penelitian terdahulu adalah kajian Muhammad Khairul Ikhwan Mohamed Nasir dan Mohd Haidhar Kamarzaman dengan judul penelitian "Sifat al-Qudrah, al-Iradah dan al-'Ilm di Sisi al-Qadariyyah dan Hubungannya dengan Kebebasan Kehendak Manusia." ${ }^{26}$ Dalam penelitian tersebut peneliti menjelaskan tentang pemahaman Qadariyah secara gamblang dalam sifat al-Qudrah (kuasa), al-Irādah (kehendak) dan al-'Ilm (ilmu) Allah serta hubungannya dengan kebebasan berkehendak manusia. Salah satu yang menjadi pembahasannya adalah apakah perbuatan manusia termasuk ciptaan Allah atau ciptaan manusia itu sendiri. Adapun penelitian ini ingin mengungkap apakah penisbahan sifat pencipta kepada manusia ada hubungannya dengan pemahaman Qadariyah ini.

\section{METODE}

Metodologi yang digunakan dalam penelitian ini adalah pendekatan kualititatif dengan metode kajian pustaka, yaitu dengan mengumpulkan pendapat-pendapat para ulama Islam terdahulu dan kontemporer dari golongan ahli bahasa Arab, ahli tafsir dan ulama-ulama generalis yang mempunyai kompetensi dan konsern dalam bidang akidah.

\section{PEMBAHASAN}

\footnotetext{
${ }^{26}$ Mohd Haidhar Kamarzaman Muhammad \& Khairul Ikhwan Mohamed Nasir, "Sifat Al-Qudrah, Al-Irādah Dan Al-'Ilm Di Sisi Al-Qadariyyah Dan Hubungannya Dengan Kebebasan Kehendak Manusia," BITARA 2, no. 3 (2019): h. 103-113.
} (2019): 114-122.

${ }^{25}$ Muhammad Muhlis, "Dimensi Syirik Dalam Konteks Privatisasi Beraagama Islam," Pancawahana 14, no. 2 


\section{Pendapat Para Ulama Terkait Penisbahan Sifat "Pencipta"}

Dalam pembahasan ini beberapa pendapat ulama dari kalangan ahli bahasa Arab dan juga ahli tafsir serta ulama-ulama generalis yang kompetensi dan konsern dalam bidang akidah.

\section{Ulama Ahli Bahasa Arab}

Dalam Bahasa Arab kata menciptakan diungkapkan dengan tiga huruf, al-khä, (خ), al-lām (ل), al-qāf (ق), dan para ahli bahasa Arab seperti Muhammad AlAnsāri, Muhammad Al-Rāzi, Muhammad Al-Fairuzabadì dan Muhammad AlHarwi telah menjelaskan secara etimologi kata khalaqa (خلق) dimana kata ini mempunyai dua makna dalam bahasa Arab, yang pertama adalah bermakna mengadakan sesuatu dari ketiadaaan tanpa contoh sebelumnya, yang kedua adalah bermakna membentuk atau menjadikan (taqdir). ${ }^{[27][28][29] ~[30] ~ I b n u ~ F a ̄ r i s ~}$ kemudian menjelaskan lebih jauh makna kedua dari kata khalaqa yaitu taqdir seperti perkataan,

$$
\text { خَلَقْتُ الأَدِيًَ للسِّقَّاءِ }
$$

yang berarti, "Saya telah membuat tempat air dari kulit hewan yang disamak," sehingga dalam kalimat ini walaupun menggunakan kata khalaqa namun maknanya adalah membuat (taqdir). ${ }^{31}$ Selain itu, di dalam al-Qur'an kata menciptakan juga diungkapkan dengan kata fatara ${ }^{32}$ (فر) yang makna asalnya adalah membelah, sehingga maknanya seakan-akan Allah membelah ketiadaan dan mengeluarkan makhluk kepada wujud. ${ }^{33}$

\section{Ulama Ahli Tafsir Al-Quran}

Dalam tafsirnya al-Tabarī mengomentari firman Allah, "Maha suci Allah pencipta yang paling baik. ${ }^{, 534][35]}$ dimana makna dari Allah pencipta yang paling baik adalah Allah adalah pembuat yang terbaik di antara para pembuat karena dalam bahasa Arab pembuat atau penghasil atau produsen (صانع) dapat disebut pencipta (خالق).

Al-Bagawī juga mengomentari ayat di atas dalam tafsirnya, beliau menyatakan bahwa makna kata khaliq (خالق) secara bahasa adalah taqdir (تقدير). Beliau pun menyebutkan perkataan Mujähid tentang ayat ini dimana makna dari ayat ini

\footnotetext{
${ }^{27}$ Muhammad bin Mukarram Al-Anșārī, Lisān Al- 'Arab, vol. 10, (Beirut: Dār Șadir, 1993), h. 87.

${ }^{28}$ Muhammad Ar-Rāzì, Mukhtār Al-Sihāh, (Beirut: Al-Maktabah Al-'Asriyah, 1999), h. 95.

${ }^{29}$ Muḥammad bin Ya'qūb Al-Fairuzabadì, Al-Qā mū s Al-Mụhịt (Beirut: Muassasah Al-Risālah, 2005), h. 880

${ }^{30}$ Muḥammad Al-Harwī, Tahzīb Al-Lugah, Vol. 7, (Beirut: Dār Ihyā' Al-Turāì , 2001), h. 16.

${ }^{31}$ Ahmad bin Fāris Al-Rāzì, Mu'jam Maqāyis Al-Lugah, vol. 2 (Där Al-Fikri, 1979), h. 213.

${ }^{32}$ Al-Qur'an, Yasin/36: 22

${ }^{33}$ Al-Ḥasan Al-‘Askari, Al-Furūq Al-Lugawiyah (Qom: Muassah Al-Nasyr Al-Islāmī, 1992), h. 133.

${ }^{34}$ RI, Al-Quran Dan Terjemahannya, h. 476.

${ }^{35}$ Al-Qur'an, Al-Mu'minun/23: 14.

${ }^{36}$ Muḥammad bin Jarìr At-Ṭabarī, Jāmi' Al-Bayān Fì Ta'wìl Al-Qurān, vol. 19. (Arab Saudi: Yayasan AlRisalah, 2000), h. 19.
} 
adalah para manusia membuat dan Allah pun membuat dan Allah adalah sebaikbaik pembuat, jika dikatakan seseorang adalah khäliq atau pencipta maka maknanya adalah sāni' (صانع) atau pembuat sebagaimana Allah menisbahkan kata khalaqa kepada Nabi Isa di Surah Ali Imran/3:49. ${ }^{37}$

Al-Bagawī dan al-Qurtubī memaknai tiga nama Allah yaitu al-Khāliq (الخالق) yang bermakna membuat atau merubah dari satu bentuk ke bentuk yang lain, alBārí (البارئ) yang bermakna menjadikan sesuatu dari ketiadaan menjadi ada, dan al-Musawwir (المصور) yang bermakna memberi bentuk dan rupa yang menjadikan satu makhluk berbeda dengan makhluk yang lain. [38][39] Ibnu Katsir tidak ketinggalan dalam memaknai tiga nama tersebut, beliau menyatakan dalam tafsirnya bahwa al-Khalqu artinya pembentukan atau merencanakan pembentukan dan al-Bara' artinya realisasi dari apa yang ingin dibentuk atau yang diputuskan, sedangkan al-Musawwir adalah merealisasikan apa yang hendak diciptakan di atas bentuk yang diinginkan. ${ }^{40}$

Ibnu Asyur dalam tafsirnya mengatakan bahwa kata al-Khalqu dalam al-Qur'an dan peristilahan syariat bermakna mengadakan sesuatu yang tidak ada, maksudnya adalah mengeluarkan sesuatu dari ketiadaan menuju ada yang tidak ada campur tangan dari manusia, karena manusia hanya mampu mengadakan sesuatu dari yang sudah ada dengan membentuknya atau menyusunnya dari bahan-bahan yang berbeda dengan metode tertentu sebagaimana produsen tembikar, maka nama al-Khäliq atau Sang Pencipta khusus disematkan kepada Allah saja, dan jika disematkan kepada makhluk dengan berdasarkan makna peristilahan syariat maka ini adalah suatu kesalahan. ${ }^{41}$

\section{Ulama Generalis}

Dalam kitabnya al-Tauhìd, Ibnu Khuzaimah menyebutkan bahwa di antara namanama Allah dan sifat-sifatnya ada yang juga yang bisa disematkan kepada makhluk dan hal ini bukan berarti memisalkan Allah dengan makhluk, sebagaimana dijelaskan secara gamblang dalam al-Qur'an bahwa Allah memiliki sifat wajah, penglihatan, pendengaran, mata, tangan dan sebagainya dimana sifat-sifat tersebut juga terdapat pada manusia namun hanya sama dalam lafaz tapi tidak sama dalam makna. ${ }^{42}$ Lebih jauh lagi beliau mengatakan, "Maka pahamlah wahai orang-orang yang berakal apa yang sudah aku jelaskan pada

${ }^{37}$ Al-Ḥusain bin Mas'ūd Al-Bagawī, Ma'àlim Al-Tanzīl Fī Tafsìr Al-Qurān, vol. 3. (Lebanon: Dār Ihyā'u AlTurās Al-'Arabīi, 1420 H), h. 361.

${ }^{38}$ Ibid, vol. 5, h. 67.

${ }^{39}$ Muḥammad bin Aḥmad Al-Qurṭubī, Al-Jāmi' Li aḥkāmi Al-Qurān, vol. 18 (Kairo: Dār Al-Kutub AlMiṣriyah, 1964), h. 48.

${ }^{40}$ Ismā'il Ibnu Kas̄ìr Al-Dimasyqī, Tafsīir Al-Qurān Al- 'Azīm. Vol. 8 (Riyadh: Dār Al-Tayyibah, 1999), h. 80.

${ }^{41}$ Al-Tūnisī, Al-Tahrî̀ Wa Al-Tanwìr, vol. 1 (Tunisia: Al-Dār Al-Tūnisiah, 1984), h. 327.

${ }^{42}$ Ibnu Khuzaimah Al-Naisābūīi, Kitāb al-Tauhīd. vol. 1. (Arab Saudi: Pustaka Al-Rusyd, 1994), h. 69. 
masalah ini, pelajarilah dan yakinlah bahwa Pencipta kita memiliki nama-nama yang bisa saja nama-nama tersebut dinisbahkan kepada sebagian makhluknya secara lafaz tapi bukan secara makna, sebagaimana yang aku jelaskan berdasarkan atas al-Qur'an dan sunah." 43

Al-Gazzăli menyatakan bahwa kata pencipta hanya pantas dinisbahkan kepada Allah saja, adapun manusia boleh dinisbahkan kepadanya secara metafor. ${ }^{44}$ Lebih jelasnya beliau menyatakan bahwa eksistensi ciptaan terbagi menjadi dua: pertama, hal-hal yang tidak ada campur tangan dari manusia seperti langit, planet, hewan, tumbuhan dan sebagainya; kedua, hal-hal yang terdapat campur tangan manusia seperti seperti hasil-hasil industri dan sebagainya. Adapun yang menjadi bagian dari manusia dalam penisbahan kata khăliq adalah yang kedua karena memang manusia mempunyai kemampuan untuk itu dimana manusia dapat membentuk atau membuat sesuatu setelah memperoleh inspirasi dari gambaran ciptaan yang terdapat pada ilmu Allah yang termanifestasi dalam ciptaan-Nya. ${ }^{45}$

Dalam kitabnya Tadmüriah, Ibnu Taimiyah menyatakan bahwasanya Allah menamakan diri-Nya dengan nama-nama yang terkhusus untuk-Nya jika dinisbahkan kepada-Nya dan tidak ada yang bisa mempunyai nama-nama tersebut selain Allah. Begitu juga dengan makhluk Allah dimana mereka juga memiliki nama-nama yang terkhusus pada mereka jika dinisbahkan kepada makhluk. Nama-nama Allah dan makhluk bisa saja mempunyai kesamaaan jika dia terbebas dari penisbahan dan pengkhususan. Seperti nama Allah al-Hayy yang terdapat pada ayat Kursi ${ }^{46}$ yang berarti hidup. Allah juga menamakan dan menyifati beberapa mahkluk-Nya dengan nama yang sama, ${ }^{47}$ namun hidup yang dinisbahkan kepada Allah berbeda dengan hidup yang dinisbahkan kepada makhluk dan akal akan memahami kadar kesamaan antara dua penamaan tersebut serta pengkhususan masing-masing yang akan menjelaskan apa yang menjadi pembeda antara Allah sang pencipta dan makhluk yang dicipta. ${ }^{48}$

Ibnu Taimiyah menegaskan, "Seperti itulah penerapan pada semua nama-nama dan sifat-sifat Allah, yang dapat dipahami darinya nama-nama yang menunjukkan kesamaan dan nama yang menunjukkan pengkhususan dan penisbahan yang tidak ada persekutuan di dalamnya antara Allah dan makhluk-

\footnotetext{
${ }^{43}$ Ibid, vol. 1, h. 69.

${ }^{44}$ Muhammad Al-GazzāTi, Al-Maqșad Al-Asnāā(Beirut: Al-Jaffān \& Al-Jābi, 2003), h. 78-79.

${ }^{45}$ Ibid, h. 78-79.

${ }^{46}$ Al-Qur'an, Al Baqarah/2: 255.

${ }^{47}$ Al-Qur'an, Al An'am/6: 95.

21.

${ }^{48}$ Taqiyyuddin Ahmad Ibnu Taimiyah Al-Dimasyqī, Tadmūriyah (Arab Saudi: Pustaka Al-Ubaikān, 2000$)$, h.
} 


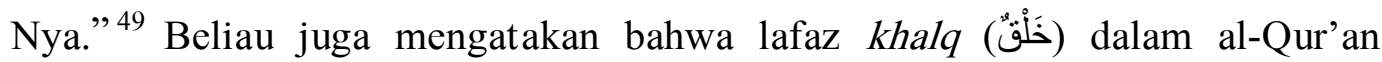
mempunyai dua makna, yang pertama adalah bermakana mengadakan dari tiada dan menumbuhkan, adapun makna yang kedua adalah membentuk. ${ }^{50}$

Ibnu al-Qayyim juga pernah mengomentari ayat terakhir surah al-Hasyr dimana Allah menyebutkan tiga nama-Nya yaitu al-Khāliq (الخالق) yang berarti menciptakan, al-Bäri (البارئ) yang berarti mengadakan, dan al-Musawwir yang berarti membentuk rupa. Ibnu al-Qayyim mengomentari ayat ini dengan mengatakan bahwa kata khāliq dan musawwir bisa dinisbahkan kepada makhluk jika yang dimaksudkan dengan kata khāliq adalah membuat atau memproduksi atau membentuk, adapun kata bäri hanya boleh dinisbahkan kepada Allah saja karena kata tersebut bermakna menjadikan sesuatu yang belum ada menjadi ada. ${ }^{51}$

Adapun al-Uśaimīn menyatakan dalam Syarh al-Aqīdah al-Wäsitiyah bahwa sifat pencipta yang disandarkan kepada Allah bermakna mengadakan dan menganti suatu wujud dengan wujud yang lain dimana makna ini hanya terkhusus kepada Allah saja. Adapun penisbahannya kepada makhluk maka itu hanyalah ibarat merubah sesuatu yang sudah ada dari sifat kepada sifat yang lain seperti kayu yang tadinya adalah batang pohon dirubah oleh tukang kayu menjadi pintu, perubahan ini bisa disebut khalq namun bukan khalq yang menjadi hak Allah secara khusus. ${ }^{52}$

Dalam penjelasan makna tauhïd rubübiyah Ibnu Usiaimin menyebutkan dengan nada serupa bahwa di antara maknanya adalah mengesakan Allah dalam penciptaan dimana manusia harus meyakini bahwa tidak ada pencipta selain Allah, namun dalam firman Allah pada surah al-Mu'minun ayat 14 Allah menyebutkan bahwa Dia adalah sebaik-baik pencipta yang menunjukkan adanya pencipta-pencipta lain namun Allah-lah yang terbaik di antara mereka. AlUśaimin mengatakan, "Ini bukanlah penciptaan yang sebenarnya, bukan bermakna mengeluarkan sesuatu dari ketiadaan menjadi ada, namun maknanya adalah merubah sesuatu menjadi sesuatu yang baru, merubah kondisi menjadi kondisi yang baru, selain itu penciptaan yang dimaksud bukan penciptaan yang sempurna, namun penciptaan yang terbatas pada kemampuan manusia dan terbatas pada kondisi-kondisi tertentu saja." 53

\footnotetext{
${ }^{49}$ Ibid, h. 22.

${ }^{50}$ Taqiyyuddin Aḥmad Ibnu Taimiyah Al-Dimasyqī, Bugyatu Al-Murtād (Madinah: Maktabah Al-'Ulūm wa Al-Hikam, 1995), h. 240.

${ }^{51}$ Ibnu Al-Qayyim Al-Jauziah, Syifā' Al- 'Alïl (Lebanon: Dār Al-Marifah, 1978), h. 131.

${ }^{52}$ Muhammad bin Șālih Al-Usaimin, Syarḥ Al-'Aqīdah Al-Wāsițiyah, vol. 2 (Arab Saudi: Dār Ibnu Al-Jauzì, 2000), h. 211.

${ }_{53}^{53}$ Al-Usaiminn, Al-Qaul Al-Mufid (Arab Saudi: Dār Ibnu Al-Jauzi, 1437 H), h. 57.
} 
Dalam kitab yang sama beliau juga menyebutkan bahwa boleh saja kata khalaqa itu disematkan kepada manusia karena di antara nama-nama Allah ada yang terkhusus hanya untuk-Nya seperti al-Raḥmān, Rabb al-'Alamīn dan yang semisalnya, dan di antara nama-namaNya juga ada yang tidak terkhusus hanya untuk Allah saja seperti al-Sämi', al-Raḥim, al- 'Alïm dan sebagainya. ${ }^{54}$

\section{Analisis Pendapat Para Ulama}

Penisbahan sifat menciptakan ini menjadi hal yang sangat perlu kita bahas karena tingginya intensitas penggunaan dan pengaplikasiannya dalam kehidupan seharihari yang mana sudah sangat dianggap biasa oleh manusia, padahal perkara tersebut mempunyai konsekuensi hukum yang erat kaitannya dengan kesyirikan apalagi jika dihubungkan dengan pemahaman Qadariyah. Telah dijelaskan sebelumnya bahwa Allah adalah satu-satunya pencipta segalanya termasuk perbuatan manusia dan sifat-sifat manusia. Berdasarkan pandangan-pandangan para ulama di atas, maka hukum menisbahkan sifat pencipta kepada makhluk perlu diperinci dan tidak bisa dinyatakan haram secara mutlak ataupun dinyatakan boleh secara mutlak.

Kita ketahui bahwa di antara nama dan sifat Allah ada yang terkhusus untuk Allah dan ada yang boleh dinisbahkan kepada manusia. Jika disandarkan kepada Allah maknanya adalah apa yang sesuai dengan keagungan dan kemuliaan Allah, tidak ada satu makhluk pun yang serupa dengan-Nya. Adapun jika penisbahannya kepada manusia, maka maknanya adalah apa yang sesuai dengan sifat manusia sebagai makhluk. Selain itu, kata al-Khalqu jika ditinjau dari bahasa Arab memiliki dua makna: pertama adalah bermakna mengadakan dari ketiadaan dimana makna ini adalah hak Allah dan tidak ada yang berserikat dengan-Nya dalam hal ini; kedua adalah bermakna membuat, dimana makna ini boleh dinisbahkan kepada manusia. Namun, kita hendaknya perlu berhati-hati karena dalam bahasa Indonesia kata al-Khāliq, al-Bāri' dan al-Fătir hanya diakomodir oleh satu kata saja yaitu "pencipta." Sedangkan nama yang boleh dinisbahkan kepada manusia adalah khaliq, sehingga jika orang Arab mengunakan kata ini maka bisa langsung dipahami bahwa maknanya adalah pembuat atau pembentuk, dan bukan pencipta. Adapun makna kata menciptakan dalam bahasa Indonesia bermakna menjadikan sesuatu tanpa bahan atau membuat (mengadakan) sesuatu yang baru atau membuat suatu hasil kesenian. ${ }^{55}$

Berdasarkan hal tersebut penisbahan kata pencipta menjadi boleh dengan dua syarat. Pertama, jika yang dimaksudkan dengan kata menciptakan adalah

\footnotetext{
${ }^{54}$ Ibid, h. 536.

${ }^{55}$ Tim, Kamus Besar Bahasa Indonesia (Jakarta: Pusat Bahasa Departemen Pendidikan Nasional, 2008).
} 
membuat, memproduksi, mengkondisikan, dan menghasilkan sesuatu yang baru dari sesuatu yang sudah ada. Kedua, objek dari kata menciptakan atau pencipta adalah sesuatu yang masih dalam jangkauan dan kemampuan manusia. Pernyataan seperti "pencipta mesin atau alat atau hasil-hasil industri" atau "pencipta lagu" termasuk boleh karena objek-objek yang disebutkan bukan merupakan sesuatu yang baru, namun sesuatu yang sudah ada, lalu kemudian disusun atau dibentuk dan diubah menjadi bentuk lain. Selain itu, objek-objek tersebut masih dalam jangkauan dan kemampuan manusia, serta posisi manusia sebagai sebab adalah sangat jelas secara nalar dan logika.

Jika kedua syarat tersebut tidak terpenuhi atau salah satunya tidak terpenuhi maka tentu saja hukumnya menjadi haram. Misalkan Jika syarat pertama yang disebutkan di atas tidak terpenuhi, yaitu jika yang dimaksudkan dengan kata menciptakan adalah mengeluarkan sesuatu dari ketiadaan menuju ada, serta meyakini hal tersebut dalam hati, maka ini tentu adalah syirik besar karena terjadi pada al-asmā' wa al-sifät (nama-nama Allah dan sifat-sifat-Nya) dimana pencipta atau al-khāliq dengan makna tersebut termasuk nama dan sifat Allah yang hanya boleh dinisbahkan kepada Allah. Konsekuensi pelaku syirik besar adalah pelakunya akan keluar dari lingkaran agama Islam dan akan terhapus amalan-amalan yang pernah dia lakukan.

Adapun jika syarat pertama terpenuhi namun syarat kedua tidak terpenuhi yaitu objek ciptaan adalah sesuatu yang berada di luar kemampuan manusia maka ini juga termasuk perbuatan syirik. Namun, hal ini perlu diperinci, jika objeknya adalah sesuatu yang di luar kemampuan manusia dan eksistensinya tanpa ada peran dari manusia seperti matahari, bulan, bintang, langit dan semacamnya maka ini juga termasuk syirik besar, karena penggunaan kata menciptakan dengan objek-objek semacam ini tidak mungkin bermakna membuat. Adapun jika objeknya adalah sesuatu yang menjadi kekuasaan dan ketetapan Allah dimana manusia sedikit atau banyak mempunyai andil sebagai sebab maka perlu dilihat maksud dari si pengucap. Misalnya dalam kalimat "menciptakan perdamaian" atau "menciptakan kebahagiaan" atau "menciptakan masa depan yang indah" atau yang semacamnya, tentu hal-hal yang disebutkan merupakan kekuasaan dan ketetapan Allah yang dengan izin-Nya manusia menjadi sebab terjadinya hal tersebut.

Jika yang mengucapkan "engkaulah yang menciptakan perdamaian" atau semacamnya meyakini bahwa Allah-lah yang menciptakan perdamaian lewat perantara manusia, maka ini boleh. Adapun jika berlebihan dalam melihat sebab 
tanpa melihat Allah yang menjadikan sebab, maka ini termasuk syirik ${ }^{56}$ karena perkataan semacam ini termasuk meletakkan sebab di atas kedudukannya. Oleh karena itu, seberapa besar pun peran sebab terhadap akibat maka tetap saja tidak mempunyai independensi dalam menjadikan akibat. Syirik semacam ini termasuk dalam kategori syirik verbal (syirk al-alfãz). Syirik verbal merupakan syirik kecil yang terjadi pada ucapan-ucapan manusia walaupun sang pengucap tidak bermaksud melakukan kesyirikan. Berbeda dengan syirik besar, syirik kecil tidak mengeluarkan pelakunya dari Islam.

Apabila perkataan tersebut dibangun di atas keyakinan bahwa manusia sebagai sebab tunggal tanpa ada campur tangan dari Allah maka ini adalah pemahaman dari Qadariyah. Perkataan dengan keyakinan seperti ini menegasikan takdir serta al-Qudrah (kuasa) dan kehendak dari Allah. Jika manusia sendiri yang menciptakan perbuatannya, maka hal ini berarti manusia melakukan perbuatan yang berada di luar kekuasaan dan ketetapan Allah, yang mana berkonsekuensi bahwa Allah tidak mengetahui apa yang akan dilakukan manusia sampai manusia itu melakukan perbuatnnya. Dengan demikian, hendaknya penggunaan kata tersebut dihindari dan diganti dengan kata lain agar lebih selamat.

\section{KESIMPULAN}

Tujuan yang ingin dicapai dengan penilitian ini adalah untuk mengetahui hukum penisbahan kata menciptakan atau pencipta kepada manusia dalam pandangan akidah Islam dan relasinya dengan pemahaman Qadariyah. Berdasarkan hasil penelitian yang telah dilakukan tentang hukum permasalahan ini, maka diperoleh hasil bahwa tidak diharamkan secara mutlak dan tidak dibolehkan secara mutlak pula, namun harus dijabarkan lebih detail. Hukumnya menjadi haram dalam dua kondisi: pertama, jika maksud kata menciptakan yang digunakan adalah mengeluarkan sesuatu dari ketiadaan menuju ada, maka hal ini tergolong syirik besar dan dapat mengeluarkan pelakunya dari Islam; kedua, jika yang dimaksudkan dengan kata menciptakan adalah membuat atau menghasilkan tapi objek dari kata menciptakan ini adalah hal-hal yang menjadi hak Allah atau halhal yang di luar kemampuan manusia, maka hal ini termasuk syirik.

Sebaliknya hukum perkara ini menjadi boleh jika yang dimaksudkan dengan kata menciptakan adalah membuat, memproduksi, menghasilkan sesuatu yang baru dari sesuatu yang sudah ada, dan objek dari kata menciptakan adalah sesuatu yang masih dalam jangkauan dan kemampuan manusia maka ini hukumnya boleh. Kendati demikian, walaupun objeknya adalah sesuatu yang berada dalam kemampuan manusia tapi jika dibangun di atas keyakinan bahwa manusialah

${ }^{56}$ Al-Usaimīn, Al-Qaul Al-Mufïd (Arab Saudi: Dār Ibnu Al-Jauzi, 1437 H), h. 504. 
yang menjadi sebabnya maka ini tergolong dalam pemahaman Qadariyah. Adapun penggunaan kata selain menciptakan atau pencipta lebih baik dan lebih selamat.

\section{DAFTAR PUSTAKA}

Al-Qur'an.

Abd Al-Wahhab, Sulaimān bin Abdullah bin Muhammad. 2002. Taisīr Al-'Azīz Al-Hamid. Beirut: Al-Maktab Al-Islami.

Al-Anșāìi, Muhammad bin Mukarram. (1993). Lisān Al- 'Arab. Beirut: Dār Sādir. Al-'Askarī, Al-Ḥasan. (1992). Al-Furūq Al-Lugawiyah. Qom: Muasasah AlNasyr Al-Islami.

Al-Asyqar, 'Umar bin Sulaimān. (2000). Al-Qạ̣ā', Wa Al-Qadar. Oman: Dār AlNafäis.

Al-Bagdādi, 'Abd Al-Qāhir. (1977). Al-Farqu Baina Al-Firaq. Beirut: Dār AlAffăq Al-Jadidah.

Al-Bagawī, Al-Ḥusain bin Mas'ūd. (1420 H). Ma'älim Al-Tanzīl Fì Tafsìr AlQurān. Lebanon: Dar Ihyāu Al-Turas̀ Al-'Arabì.

Al-Bukhārì, Muḥammad bin Ismā'ìl. (1978). Khalqu Af'āl Al-'Ibād. 1 ed. Jeddah: Dar Al-Ikāz. . (2001). Shahih Al-Bukhārī. Beirut: Dār Tuq Al-Najāh.

Al-Dimasyqī, Ismā'il Ibnu Kasīir. (1999). Tafsìr Al-Qurān Al-'Ażim. second ed. Riyadh: Dār Al-Tayyibah.

Al-Dimasyqi, Taqiyyuddin Ahmad Ibnu Taimiyah. (1995). Bugyatu Al-Murtād. Madinah: Maktabah Al-'Ulūm wa Al-Hikam.

. (1995). Majmū' Al-Fatāwa. Madinah: Majma' Malik Fahd. . (2000). Tadmuriyah. Arab Saudi: Pustaka Al-Ubaikan.

Al-Fairuzabadi, Muhammad bin Ya'qūb. (2005). Al-Qamūs Al-Muhit. Beirut: Muassasah Al-Risālah.

Al-Gazzāli, Muhammad. (2003). Al-Maqșad Al-Asnā. Beirut: Al-Jaffān \& AlJābi.

Al-Ḥakamī, Hāfiz bin Aḥmad. (1990). Ma'âriju Al-Qabūl. Dammam: Dār Ibnu Al-Qayyim.

Al-Harwī, Muhammad. (2001). Tahżīb Al-Lugah. Beirut: Dār Ihyā' Al-Turä̀. Al-Jauziah, Ibnu Al-Qayyim. (1978). Syifă' Al- 'Alïl. Lebanon: Dār Al-Ma'rifah. Al-Naisabūrī, Ibnu Khuzaimah. (1994). Kitāb at-Tauhịd. Arab Saudi: Pustaka AlRusyd.

AL-Qurțubì, Muḥammad bin Aḥmad. (1964). Al-Jāmi' Li ạ̣kāmi Al-Qurān. Kairo: Dār Al-Kutub Al-Mișriyyah.

Al-Rāzìi, Ahmad bin Fāris. (1979). Mu'jam Maqāyīs Al-Lugah. Dār Al-Fikri.

Al-Sa'di, Ảbd Al-Raḥman bin Nāṣir. (2011). Taisìru Karìmi Al-Raḥmān Fï Tafsìri Kalāmi Al-Mannān. Dammam: Dār Ibnu Al-Jauzī.

Al-Tūnisī, Muhammad Tạhir bin 'Asyūr. (1984). Al-Tahrìr Wa Al-Tanwïr. Tunisia: Al-Dār Al-Tūnisiah. 
Al-Ussaimīn, Muhammad bin Ṣāilih. (1437 H). Al-Qaul Al-Mufīd. Arab Saudi: Dār Ibnu Al-Jauzi.

. (2000). Syarh Al-'Aqīiah Al-Wāṣitiah. sixth ed. Arab Saudi: Dār Ibnu Al-Jauzi.

Ar-Rāzì, Muḥammad. (1999). Mukhtār Al-Ṣiḥăh. Beirut: Al-Maktabah Al'Așriah.

At-Tabarī, Muhammad bin Jarìr. (2000). Jāmi' Al-Baȳan Fì Ta'wīl Al-Qurān. Arab Saudi: Yayasan Al-Risālah.

Kamus Besar Bahasa Indonesia. (2008). Jakarta: Pusat Bahasa Departemen Pendidikan Nasional.

Malkawī, Muhammad. (1985). 'Aqīidah At-Tauhìd Fì Al-Qurān Al-Karìm. Madinah: Maktabah Dār Al-Zamān.

Muhlis, M. (2019). DIMENSI SYIRIK DALAM KONTEKS PRIVATISASI BERAGAMA ISLAM. Jurnal Studi Islam: Pancawahana, 14(2), 114-122.

Nasir, M. K. I. M., \& Kamarzaman, M. H. (2019). Sifat al-Qudrah, al-Iradah dan al-'Ilm di Sisi al-Qadariyyah dan Hubungannya dengan Kebebasan Kehendak Manusia. BITARA International Journal of Civilizational Studies and Human Sciences, 2(3), 103-113.

RI, Departemen Agama. (2006). Al-Quran Dan Terjemahannya. Jakarta: Darussalam. 